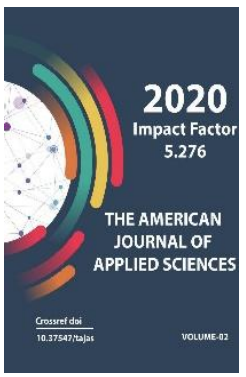

\title{
The History Of Studying The Poetry Of Sorrowfull Time
}

Pertaeva Elmira Kulibaevna

Docent, Candidate Of Philological Science Taraz Innovative Humanitarian University, Taraz

Kazjanov Galim Tulegenovich

Master Student Of Pedagogical Science Taraz Innovative Humanitarian University, Taraz

Journal Website:

http://usajournalshub.c

om/index,php/tajas

Copyright: Original content from this work may be used under the terms of the creative commons attributes

4.0 licence.

\section{ABSTRACT}

In this article the works of poets of hard times (Dulat, Shotanbay, Murat) are analyzed in the context of time truthfulness.

\section{KEYWORDS}

sorrowfull time, Kazakh literature, spaces (aktandak)

\section{INTRODUCTION}

In the literature and culture, history and art of the Kazakh people, there are a lot of "aktandak" (gaps) moments. Gaps are not a separate problem in studying the history of Kazakh literature, but a complex problem that covers the entire path of its development [Kirabaev, 1988]. One of the "gaps" in the memory of such people is the poetry of mourning.
The most common period of mourning songs in folk literature, which begins with prophetic verses, is the colonial era. It was difficult for the Kazakh people when several centuries ago Asankaygy was captured by a group of foreigners, which our ancestor Bukhar held in his hands, called seeing with his own eyes when several strangers hit our targets and lakes. 
It's time to mourn and mourn. The state of mourning, which began in the depths of centuries and affected the sorrows and needs of the country, came to the fore. As M. Auezov said: "It was one of the long-awaited horrors of the Kazakhs, and it became a reality. In addition to acquiring land, it first circled the Kazakh steppes and built peripheral cities. Russian black-tailed deer were brought in abundance. The former khan, a straight man who took care of the former country, everyone was repelled and whispered, but everything was done by the Russian government, by Russian hands. One law after another, and the life of the country began to shrink. Elections, power, behavior, migration - everything is in the hands of foreigners, not in the hands of the country [Auezov, 1991a].

S. Mukanov also wrote about this historical period: He wrote that "fiction" is the literature of people born by the screams of people suffocated from grief when this power was lost [Mukanov, 1942]. In recent years, the scientist $M$. Myrzakhmetov suggests calling literature "Mournful time" against the antiRussian colonial nature: "Literature of the colonial era" [Myrzakhmetov, 1993]. Scientist M. Auezov: "Lamentation" is the title of a poem by Shortanbay, who lived in the 19th century.

Shortanbay's poems are a collection of poems by all the great poets of the past and recent times, so we called the poets who sang the same poems throughout the era "Poets of the Sorrowful Time," he said. [Auezov, 1991a]. The allocation of the following questions testifies to the "literary mourning course" in $M$. Auezov's systematization:

Who are the poets of our time?

What poetry unites the poets of the sorrowful time?

What questions were raised by the poets of that time?
"If the first generation of poets of the mourning period began in the time of Abilay, then the opposite came to Abay" [Auezov, 1991a], - the author calls the Asan mountain as his first representative. M.Auezov said that in antiquity Sipira jirau, Kaztugan Bergi Alasha Baitok jirau, Bazar jirau, Doskojas occupy a large place in the era of mourning. We aimed to show the location of each species by dividing it into separate segments, depending on their appearance and meaning, "he said. [Auezov, 1991a]. Therefore, after Asankaigy, Bukhar passes to jirau. "Most modern poets have followed the movements of Isatai, Makhambet and Kenesary since the middle of the 19th century. After the tragic end of the movement of Isatay-Kenesary, which awakened the Middle Djuz and the Younger Djuz, the mountains of the country collapsed, the hopes of the country collapsed, there was little hope for the future. Therefore, in the middle of the 19th century, the state of mourning will be recognized throughout the country" [Auezov, 1991a]. This is well said in the works of K. Jumaliev, Kh. Dosmukhamedovich, B. Suleimenov, Kh. Suinshaliev, K. Madibay, B. Omarovich. Thus, the desire of the Kazakh people to wear the yoke of spiritual slavery and escape from colonial oppression could not but create a actual theme of Kazakh poetry of this period. Representatives of the new dynasty, headed by Abay, Asankaigy, Bukhar, Makhambet, Dulat, Shortanbay, Murat of the past, feel the irony of internal resistance to colonialism in the works of scribal poets. Although this common theme is reflected in the poetry of poets and poetesses who lived in different periods of different political and social changes, there is only one truth that defines the main theme. It lies at the heart of the poetry of the poets who opposed the injustice in the country's governing system that stems from colonial politics. The main theme of the poem is the cruel policy of the colonial akims and the natural protest against the actions of local officials who colluded with the 
colonialists. "Literature reached great heights in the history of the Kazakh people, and it produced thought leaders who could understand the breath of that era. For example, the period of formation and disintegration of the Nogai community presented the wise Jiraus, who managed to fill these historical conditions, the grief of the legendary Sipira and Asan; The wars between Kazakhs and Kalmyks gave birth to great poets who recreated old songs or created new epic songs. The era of the reunification of the Kazakh people - the historical circumstances of the 18th century gave Bukhar jirau. "These poets preached" The homeland of the Kazakh people, protection from external enemies, "said K. Umiraliev, a literary researcher [Babataevich, 1991]. Thus, it can be said with confidence that it was the collapse of the colonialists that raised the poets of the mourning period to the level of activity. Back in the days of Az-Janibek Khan, our ancestor Asankaigy:

Ay,Janibek, oylasan,

Qili-qili zaman bolmay ma,

Suda jurgen aq shortan

Qaragay basin shalmay ma,

Muni ele nege bilmeysin? -

How can we refute the primordial thoughts of our ancestor Asankaigy, who long ago, during the time of Az-Janibek Khan, feared and warned about the dangers of colonialism that came long ago. Although the topical part of this story is in the songs of Sipira Jirau, it is not in vain that Bukhar jirau decides to do this. Bukhar jirau:

Qaragay sudan qashiqtap,

Sholge bitken bir daraq.

Shortan sholge shidamsiz,

Baliqtan shiqqan bir qaraq.
Oylama shortan ushpas dep,

Qaragayga shiqpas dep,

Kunbatistan bir dushpan

Aqirda shigar sol tustan...

In fact, it seems that the pike cannot climb the pine tree. How to catch a pike in the water to climb a tree in the mountains. You can immerse yourself in the wealth of the case, study deeply, do the impossible. It was a fact that was reflected in literature and in the minds of people.

The poet of mourning Murat, who once witnessed the beginning of times when Asan grief and Bukhar jirau were in danger, wrote in his poem "Kaztugan":

Azamat erdin balasi

Jabiqqanin bildirmes

Jamandar mazaqqilar dep.

Baytoqtin basi patshalar

Batuga jalgiz asa almas

Kokjaldar kozin salar dep.

Men zamannan qorqip baramin

Keyingi osken jas bala

Kiiriptarda qalar dep.

Kunderdin kuni bolganda

Obali magan bolar dep, -

The poet Murat, who once witnessed the beginning of the time of Asan's sadness and fear of Bukhar jirau, wrote in his poem "Kaztugan": He said that he would take his wealth and plunder it. The poet's words "I'm afraid of time" are in tune with the present, and we see that he is sad and sad for the future. Shortanbay saw a distorted version of that time:

...Kapirdi kordin pirindey, 
Tilmashti kordin jengendey.

Duandi kordin uyindey,

Abaqti tur qasinda,

Qazilgan qara korindey -

Murat could not contain his anger and hatred:

Aueli jenip oris Edildi aldi,

Saritau, Ashtarhanningjerin aldi.

Artinan Edilden son Narindi aldi,

Togaydin agash, qamis, talin da aldi -

This threat is the policy of the tsarist government to russify the Kazakh people. Strengthening this colonial policy threatened to deprive people of both national spiritual culture and religion. This is due to the fact that people, having moved away from their busy daily activities and comfortable places, again turned their attention to the nomadic way of life. In this regard, M. Auezov said: "Because of such reasons of external life, the Kazakhs became anxious, depressed, lost all words, poems, colors, masculinity, freedom, and instead dreamed, cried, mourned" [Auezov, 1991 b] - should not be overlooked. Indeed, since the formation of the Kazakh people, the country has experienced both joys and sorrows. If you pay attention to the background of the most ancient words, you will hear the cry of the Kazakhs. The Jirau tradition, which became widespread in the 16th-17th centuries and reached its apogee in the work of Bukhar, in the 30s-80s of the 19th century opened the way for the development of realistic literary methods in the works of Dulat, Makhambet, Suyunbai. Dulat was a realist poet who, in his works, deeply revealed the contradictions of the supreme sultanate and strongly protested against the annexation of the Kazakh people to tsarist Russia. Scientist Kh. Suinshaliyev says: "Dulat is a poet, fighter and realist who radically opposed the time he created, the colonial violence, the akims he served, the senior sultanate who strove for the independence of the people" [Suinshaliev, 1997]. The basis of his work is the reality of life. Thus, the bitter words of the mourning poet Dulat are used to express the truth, to express reasonable thoughts. The poet Dulat:

Ag'a sultan qazining',

El silkindi isinen.

Awilding'atqamineri,

Jemtikke qong'an kushigen.

O'zi toysa ma'z boldi,

El irgesin saqtamay.

The poet vividly describes the tyrannical actions of the highest sultans of that time, who did not care about Bukharians, but only the black head.

Mayirding' alsa buirig'in,

Borbayg'a qisip quyrig'in,

El piisig'i jortadi

O'zi eldi qorqitip,

Onan o'zi qorqadi.

Dulat's poems criticize the country's governors not only as tyrants, oppressors and suckers, but also as traitors to the royal power. The poet Dulat:

Shen-shekpenge qumartqan,

Qantalap ko'zi munartqan,

Saudalap elin tiyng'a,

Qumartip uliqsyina,

Bek degening' bek emes,

Xan jalshisi no'keri -

Poet Shortanbay said:

Oris -burkit,biz-tulki, 
Alamin dep talpindi.

Oristan qorliq ko'rgen son',

Otirip biler alqindi...

Arqanin' jazin qashirg'an,

Jilqining' etin jemesti.

Jagalasqan minau jau,

Ketirer sonda siqin'di,

The lament, which occasionally touches history, sheds light on the truth of modern poets. Similarly, a number of works by Suyunbay Aronuli depicting the collapse of colonialism are close to modern literature. His works reflect a number of realities of the political and social situation of his time. Poet Suyunbay:

Suyunbay Alatauday atim darday,

Jatqanimda boldim g'oy sho'kken narday.

En’begimnen eki auiz so'z qalmastan,

Ko'ktemdegi jer tartti ketlen qarday.

Aqilimdi qarang'l qalg'an basip,

Sau kunimde qudayim eske salmay.

Auru bilep boyimnan alim ketti-au,

Bauirsaqqa ilegen kesken nanday -

The great poet's anxieties, lofty dreams, lofty ideals - all this seems to fit into one poem. Suyunbay's creativity is harmoniously combined with the work of the modern poet Dulat. This is primarily due to the similarity of the topic. Dulat said to Barak:

Quriq derdin' urig'a,

Momindi aldin' qirin'a -

And Suyunbai to Tezek:

Zar jilatip momindi,

O'risten malin alasin', -
We know from all our history that our ancestors were as gentle and kind to their friends as they were to their enemies. When they got on their windswept horse, they ignored everyone and said that no one was alive except them. They pierced the sky with a mustache, traveled to some parts of the world and conquered some parts. It seems that our great-grandfather considered himself a descendant of the Blue Wolf. That is why the head of the sacred wolf was attached to its flags, spears and bows. At the same time, referring to the poet Suyunbay, he said:

... Tu tusirip jau alg'an,

Shapirashti batir babamiz.

Bori basi uranim

Borili menin' bayrag'im.

Borili bayraq ko'terse,

Qozip keter qaydag'im -

The song "Elim-ay", which begins with the words "Elim-ay", begins with the song "Elimay, elim-ay", which is full of hardships, sufferings and tragedies of our people. The song "Borili Menin Bayragim" seems to convey the words of the poets who in ancient times called on the country to ride. Another fact in the literature of this period is the loss of the original profession and the destruction of our religion and traditions. The poet Shortanbay says about this fact:

Aqsaqaldan a'l ketti,

Almaydi onin' ken'esin.

Starshin qoygan bolipti,

Qaydag'i pisiqsing'an nemesin'.

Zaman ketti Qirimg'a,

Buring'l shirkin zamannin',

lysi de kelmes muring'a.

Bittey narse qalsayshi, 
Burin'g'i zan'nan irimg'a.

This is especially remarkable. Although Shortanbay lived in Ark, Dulat in the East of the Kazakh people, Murat in the West, in the works of each of them the truth of the same era and is expressed with deep philosophical thought. "Boldly speaking the historical truth, writing about it is the main requirement of our life today [Moldakhanov, 1992]. Thus, as we gain complete freedom and a bright future, the gaps in our history and the lessons of our past need to be rethought and rethought. Various problems of preserving our country and sovereignty, the development of our religion and language, as well as unrest caused by internal and external forces, show that our modern civilization is unnecessary.

\section{REFERENCES}

1. Kirabaev S (1988) Respect for talent. Almaty: Writer, 248 p.

2. Auezov M (1991) History of Literature. Almaty: Ana tili, $222 \mathrm{p}$.

3. Mukanov S (1942) Essays on the history of Kazakh literature of the XIXXIX centuries. Almaty: Kazakh United State Publishing House. 247 p.

4. Myrzakhmetov M (1993) Literature in the colonial era // Juldyz. №7. P.181192.

5. Babataevich D (1991) Contemporary music: Poems and epics / Comp. K. Umiraliev. Almaty: Writer. $160 \mathrm{p}$.

6. Auezov M (1991) The main epoch of Kazakh literature. Almaty: Alem. 291 p.

7. Suinshaliev X (1997) History of Kazakh literature: Textbook. Almaty: Sanat. $443 \mathrm{p}$.

8. Moldakhanov A (1992) Were there any gaps in our original literature? // Kazakh language and literature. 1992. №10, 11, 12. P. 7- 